\title{
The effects of tax avoidance on corporate value
}

\author{
Mohammed Azam \\ School of accounting, Dongbei University of finance and economics, Dalian, Liaoning, China \\ E-mail: mazzam1988@gmail.com \\ Man Wang \\ School of accounting, Dongbei university of finance and economics, Dalian, Liaoning, China \\ E-mail: manwang@dufe.edu.cn
}

\begin{abstract}
Taxes considered a significant cost to the corporations and shareholders, and it generally expected that shareholders prefer tax avoidance. However, the purpose of this paper is to shed light on the effects tax avoidance on firm value. Based on a sample of 34 Palestinian listed firms from 2011 to 2018, the authors use OLS regression. The results shows that firms tend to take advantages from cash flow saved from aggressive tax practices. On Palestinian context, our results are interesting. Palestine is very unique environment, since investors rights are weakly shielded, furthermore, Palestine stock exchange market is not developed enough, this arguments leash firms to benefit from tax savings, while investors didn't need to transfer profits to other lower tax countries, since tax rate in Palestine considered low comparing with other countries negative relationship with tax avoidance. This study has spotlight on tax avoidance on unique environment in Palestine and thus extend literature that focused on developed countries. Simultaneously, considered as basis in Palestine and other Arab countries for future research in this area. Although the last implications of this study, it still has limitations, one is limited sample scope, as Palestine exchange market has few listed firms, as small country with precarious political situations. However, The study is the first that focused on the relationship between four forms of ownership structure and tax avoidance in unique environment as Palestine with very distinguished political and economic situations.
\end{abstract}

Keywords Tax avoidance, Firm value, Effective tax rate , ROA

DOI: $10.7176 /$ RJFA/11-4-13

Publication date: February $29^{\text {th }} 2020$

\section{Introduction}

Tax avoidance plays significant role in corporate strategy (Hanlon and Heitzman, 2010a). Normally, it has believed that firm tax avoidance means wealth transfer from states to firms and should increase corporate value (Slemrod, 2007). Moreover, tax avoidance has cost. Direct costs include preparation cost, reputation cost and potential fin, etc. Agency theorists define that tax avoidance practices also connected with corporate governance matters. Mysterious tax avoidance practices bring flag to managerial rent diversion and enlarge corporate value (Desai and Dharmapala, 2006) (. Hence, whether a firm involve in tax avoidance relies on whether gains be more thank losses. This research extends the tax avoidance literature by analysing the impacts of tax avoidance practices on corporate value in Palestine. We anticipate the relation of tax avoidance and firm value alters with various stage of corporate governance. Whether tax avoidance practices fosters firm value is an important but in range of research questions. Prevailing empirical evidence on stockholders reactions to tax avoidance is assorted. The literature on information subject of tax avoidance indicate that income tax expense is an predictor of firms profitability. Tax avoidance shorten the content of income tax expense (Hanlon and Heitzman, 2010a). (Desai and Dharmapala, 2009) determine that the overall influence of corporate tax avoidance practices on corporate value is not significantly different from zero. The influence is positive just for those firm-years with great levels of institutional ownership. They suggest that firm tax avoidance has two competing impacts on corporate value. While it represent a wealth pass from government to owners, the agency conflicts between management and shareholders rise the potential of managerial diversion, which is a minus of corporate value. (Slemrod, 2007) analyse the market interaction to news about tax shelter practices. They find modest proof on cross-sectional fluctuation of market reaction. (Chen et al., 2010)finds that shareholders place a value add on tax avoidance, but the price increase, decreases as firm opaqueness rise. Apparently, the incompatibility of research determinations may be somewhat due to different choice of component of concern, which have varying impacts on cash flows now and on future and maximum firm value, and partially due to divergence in sample selections and research viewpoints. For the basic reason, in specific, tax avoidance can enforce direct and indirect vary on cash flows now and on future. For example, immediate changes incorporate that tax avoidance can increment cash flows through saving tax whereas it is also related to higher agency costs (growing management firm-paid consumption, the creating of "personal empire", etc.). Besides, aggressive tax avoidance complicates business financial activities, derive to weaker 
information transparency and lower firm value in an indirect path. Overall, the net impact of tax avoidance on firm value is an experimental question. The appearance of superior affecting factor relies on particular firms operating atmosphere and institutional settings. In this paper, we analyse the impacts of tax avoidance on firm value in Palestine listed companies. The reason for that due to serious agency problems due to weak corporate governance implementation. Hence, Palestine is an interesting setting to analyse the agency theory interpretations of how tax avoidance affect firm value. Recent literature suggests that data transparency, defined as the availability of corporation's information to all users outside publicly traded companies, can role as effective corporate governance to minimize interest conflicts between stakeholders(Armstrong et al., 2015). Previous studies presents that information transparency can instantly conduce to economic performance by regulating corporate insiders in better choice of opportunities, more effective management of assets in place, and decrease expropriation of minority shareholders' wealth (Bushman and Smith, 2003). Corporate decision making depends on quality and quantity of information, Hence information transparency could move current and future cash flows by affecting management decision making.

This paper contributes to the agency theory studies on corporate tax avoidance practices in Palestine exchange market. To our best knowledge, it present the first piece of proof relating to shareholders - management reaction to Palestinian listed firms tax avoidance practices and obtain insights into corporate governance. Our results show that, first, agency loss and other non-tax losses are relatively high in Palestine ; second, investors in Palestine do not place value maximizing on tax avoidance practice for these forms of activities could cover management rentseeking attitude. Finally, information transparency can minimize the negative impact of tax avoidance practice on firm value, that is, tax avoidance is more seems to obtain in profits for transparent corporations than opaque ones. The rest of the research proceeds as follows. Section 2 literature reviews and hypothesis development. Sample selection and design are shown in Section 3. The econometrics model and variable measurements presented in Section 4, and present the empirical findings and recommendations in Section 5.

\section{Literature review and hypothesis development}

Many studies suggests that information transparency act a key role in boosting the efficiency of management rewards contract (Chen et al., 2010; Kim and Zhang, 2016a). And formative securities analyst predict characteristics (Fan and Wong, 2002) Suggest that there is a U- moulded relation between information transparency and corporate market value. In our study, we are answering if it act a role in the relation of tax avoidance and firm value by reducing agency conflict. With 25 years of development of Palestine security exchange, listed firms have made significant efforts in establishing information disclosure.

Tax avoidance is widely defined as the minimizing in a companies' explicit tax obligations (Dyreng et al., 2017). Under this definition, tax avoidance constitute a range Of tax planning strategies since completely legal practices are at one end and more Aggressive practice could be closer to the other end (Hanlon and Heitzman, 2010a) Vary disciplines differ in literature perspectives relating how and why firm Income tax affect firm value. Finance studies focuses on the impact of debt-as-tax protector on financing decisions(Kiesewetter and Manthey, 2017) .

Economists explain how illegal tax avoidance influence firm value (Hanlon and Heitzman, 2010a) And how agency theory can prepared on tax avoidance impacts on firm value (Desai and Dharmapala, 2009). Accounting researchers prefer to examine how tax avoidance could influence financial reporting and value importance of taxation information (Allingham and Sandmo, 1972) So far, there is lack of comprehensive conceptual studies to assimilate research outcomes across disciplines. Traditionally, tax avoidance viewed as Tax-saving method, and there is no other economic encourage other than saving tax. By contrast, agency theorist's claims that tax issues are interacted with corporate governance due of widespread agency conflicts. It is impossible to detect tax avoidance in a vacuum. In reality, the real motive for management to involve in tax avoidance is to complicate and obfuscate the information process, which provides executives with shelter for self-interest behaviour (Desai and Dharmapala, 2008). Other proof Also supports their point. In the 1990s, Enron leveraged masked up financing transactions to avoid tax and manipulate profits, which ultimately led to its failure.

Empirical studies on the effect of tax avoidance on corporate value is mixed. (Dey, 2008) argued that tax avoidance is seems to improve value for well-governed Companies but it is not the case for poorly-governed companies . However, other research findings are inconsistent. (Slemrod, 2007) explain market reflection to application of tax shield. On average, shares prices are falling at announcement, but the cross-section variation is little and only significant to the retailing sector. (McGuire et al., 2011) finds that transparent companies are more aggressive to avoid tax than their different counterparts are. She also out that investors react positively to tax avoidance but corporate value decreases as transparency is lower. How to account for the instability of research outputs? Theoretically, it is probably that tax avoidance practice provides firms with more extra cash flow either in the short 
term or in the long term, which directly increases corporate value, and the Tax avoidance itself will shift cash flows indirectly by influencing management.

Decision-making. In reality, the ambiguity of tax avoidance allow management to gather the gains into themselves, which could decrease current and future cash flows. And so far, relating to classic agency theory, the extra cash flow resulting from tax avoidance would derive to the existence of company-paid liabilities and the constructing of "personal empire", which will reduce future cash flow and reduce corporate value. Moreover, aggressive tax avoidance practice is connected with administrative penalty and potential reputation loss, which reduce future cash flow and corporate value. Other indirect impacts of tax avoidance include cloudy financial information(Wilson, 2009), increasing potentially of earnings management(Frank et al., 2009) and increasing cost of capital(Goh et al., 2016).Thus, we believe that the connecting of tax avoidance and corporate value is an empirical question. The emergence of dominant impact is dependent on a variety of roles, including the institutional placement and operating scope, and the ultimate influence is the equilibrium output of all involving sectors.

Other empirical studies focused on tax avoidance practices determinants. For instance, (Wu et al., 2013) examines the impacts of state ownership and favourable tax arrangement on firm tax liabilities. He finds that firms tax liabilities increase with the share of state ownership, and state ownership imposes a stronger tax burden on corporation unfavourable tax treatment than corporations with favourable tax treatment. (Derashid and Zhang, 2003) claims that in districts with heavy taxation enforcement, the agency costs will be reduce, and the tunneling and connected party transactions will be lower for most of shareholders, thus they believe taxation enforcement can play as an external corporate governance mechanism. (Lin et al., 2014) out those firms with more political interaction involve in more tax avoidance behavior. Current Chinese studies could not explain why firm's tax avoidance practice differs, which is the exact void we are trying to fail. As far as Chinese institutional environment is concerned, and Zhu (2007) conclude that the governance mechanism of Chinese listed firms has obvious drawbacks, such as government intervention, poor investor legal protection, controlling of major shareholders, loose supervision from state-owned banks and the absence of external CPA governance. These flaws intensify two kinds of agency problems. One is between shareholders and managers, and the "owner absence" causes more severe agency problems in China; the other is between controlling shareholders and minority shareholders. The controlling shareholders can dominate personnel arrangements for board of directors and top management, and engage tunneling through related party transaction. (Ayers et al., 2009) find that tunneling has tax effect as well, and it leads to firm value loss in the long run.(Dhaliwal et al., 2006), Suggest in areas with strong taxation enforcement, controlling shareholder is less likely to expropriate assets and conduct related party transactions. They point out taxation enforcement as corporate governance mechanism. Using financial data of big and mediumsized enterprises released by the Bureau of National Statistics, (Chen et al., 2016) explain the corporate governance problems of non-listed firms. Their study suggests that the effects of the external legal environment significantly decreases agency costs for non-listed firms, and taxation enforcement can potentially serve as corporate governance. As for the information content of tax expense, corporate income tax expense can be viewed as an indicator of profitability (Chen and Yuan, 2004) and has explanatory power of annual stock return (Cai and Liu, 2009) . Given Chinese institutional setting, the agency perspective may better explain the relation between tax avoidance and firm value

\section{H1. Ceteris paribus, tax avoidance behavior is positive associated with firm}

\section{Research design:}

3.1 Sample selection and data collection

The data gathered from two sources that are companies' annual financial statements listed in Palestine Stock Exchange Market (http://www.pex.ps) and OSIRIS database of financial information. Firms 'annual reports are used to collect manually the effective tax rate (ETR) and the ownership structure information.

Companies those included in the study are all non-financial listed companies on Palestine Stock Exchange Market. However, the financial listed companies (Banks and insurance firms) excluded, because they follow specific lows and regulations. Consequently, the study population consists of 34 non-financial listed firms as shown on Table 1, that belong to manufacturing, investment, and service sectors for the fiscal year-ends ranging from 2011 to 2018 We exclude company-years that are missing values, and observations with negative or zero pre-tax income Which lead to final results 278 company-years observations. Following (Gaaya et al., 2017) 
Table 1 industry classification

\begin{tabular}{lcr}
\hline Sector & No. firms & Percent \\
\hline Service & 12 & 35.3 \\
Industry & 13 & 38.2 \\
Investment & 9 & 26.4 \\
\hline Total & 34 & 100
\end{tabular}

\section{3-2 Variable Measurements Independent variable}

ETR has been a widely used measure of tax avoidance, its calculated as the total tax expenses divided by the profit before tax. (Derashid and Zhang, 2003; Gebhart, 2017; Hanlon and Heitzman, 2010b), Thus, it conclude the aggregate portion of the accounting income payable as taxes (Salihu, 2016) . we conclude tax avoidance by comparing statutory tax rates STR with effective tax rate of companies on Palestine which is $15 \%$. moreover, we consider ETR variable based on pre-tax operating cash flow as the denominator as documented by (Buijink et al., 2002; Zimmerman, 1983). The point here is to accurate the influence of preparation choices of financial accounting that may interconnected, to explanatory variables in the model more over ETR is an opposite function of tax avoidance, as lower values of effective tax rate

Imply bigger engagement in corporate tax avoidance (Frank et al., 2009)

Thus, we conduct two ETR measures, which are:

ETR1 $=$ Income tax expense scaled by profit before interest and tax

ETR2 = Income tax expense scaled by operating cash flow

Dependent variable Measure of Firm value :

We used Return on Assets to measure firm value, which used widely to present profitability of companies ROA is the ratio of return on assets ratio (ROA). Profitable firms have more benefits to involve in corporate tax avoidance to reduce their tax burdens (Minnick and Noga, 2010; Richardson et al., 2013).

\section{Econometric specification}

To test our hypotheses, we specify the following ordinary least squares (OLS) regression model:

ROA ${ }_{i t}=\alpha_{0}+\alpha_{1}$ ETR1 $_{i t}+\alpha_{2}$ ETR2 $_{i t}+\alpha_{5}$ INDTYP $_{i t}+\alpha_{3}$ LEVG ${ }_{i t}++$ YEAR4 it $+e$

Where Tax avoidance is either the firm's ETR1, or ERT2, We also used control variables that could affect companies proprieties, regarding to tax avoidance behavior, LEVERG is the ratio of total long-term debts over total assets. (Badertscher et al., 2013; Richardson et al., 2013) resulted a positive relationship between leverage and tax avoidance given tax-deductible-interest payments. INDTYP it dummy variable; representing three industry types "manufacturing, investment, and service sectors.

\section{Results and analysis :}

\subsection{Descriptive statistics}

Table 2 reports the summary statistics of our dependent and independent variables. The mean of ROA is .010 while the mean values for ETR1 and ETR2 are .132 and .1629 per cent respectively. These results show a reasonable level of corporate tax avoidance compared to those reported by (Minnick and Noga, 2010) .The level of corporate tax avoidance measures varies significantly between our sampled firms. The lowest level of ETR1, ETR2 are $.010, .019$ respectively . 
Table 2 Descriptive statistics

Table 2

\begin{tabular}{lccrr}
\hline \hline \multicolumn{1}{c}{ Variables } & Mean & SD & Minimum & Maximum \\
\hline \hline & & & & .2015 \\
ROA & .010 & .0192 & -.52 & .152 \\
ETR1 & .132 & .2345 & .010 & .1625 \\
ETR2 & .1629 & .1796 & .019 & .823 \\
LEVERG & .1239 & .1996 & 0 & 1 \\
INDTYP & .273 & 0.2539 & 0 & 1 \\
\hline
\end{tabular}

Notes Table 2 presents, descriptive statistics for targeted sample of 34 Palestinian companies listed in Palestine stock exchange market, ROA is of income before tax scaled by total assets ETR1 is total tax expenses over pretax income, ETR2 calculated by total tax expenses over operating cash flows, s , , LEVERG is the ratio of total long-term debts over total assets

\section{5-2 Correlation matrix}

Table 3 presents Pearson correlation between variables used in empirical regressions. We find ROA and ETR1 and ERT2 significantly positively correlated, ETR1 and ETR2 as inverse function of tax avoidance. Moreover, the correlation between independent variables is small we tested multicollinearity between independent variables using regression model, we used variation inflation factor (VIF) to test for the multicollinearity issue Table 4, VIF range between 1.06 and 1.84 which is below level of 10 (Neter etal.,1996) which support that multicollinearity issues are eliminated

(Table 3) spearman correlation matrix

\begin{tabular}{clllll}
\hline & \multicolumn{1}{c}{ ROA } & \multicolumn{1}{c}{ ETR1 } & ETR1 & LEVERG & INDUS \\
\hline ROA & 1 & & & & \\
ETR1 & $0.676^{* * *}$ & 1 & & & \\
ETR2 & $0.0757^{*}$ & $0.176^{* * *}$ & 1 & & \\
LEVERG & $-0.0130^{*}$ & $-0.0135^{*}$ & $-0.162 * * *$ & 1 & \\
INDUS & -0.0672 & $0.0631^{*}$ & -0.0608 & $-0.132 * *$ & 1 \\
\hline
\end{tabular}

Note : ROA is of income before tax scaled by total assets ETR1 and ETR2 as inverse function of tax avoidance, LEVER is the ratio of total long-term debts over total assets, INDTYP it dummy variable; representing three industry types "manufacturing, investment, and service sectors.

$; * * *, * *$, are significance levels at 1,5 and $10 \%$, respectively

\section{5-3 multivariate analysis}

Table 4 illustrates the results of the effects of tax avoidance on ROA, we can observe positive and statistically significant relationship firm value and tax avoidance. In both measures of tax avoidance. Table 4 suggest that this results support hypothesis of positive relationship between tax avoidance and firm value . (Shleifer and Vishny, 1997) , which documented that positive relationship between firm value and tax avoidance .

Furthermore, support the hypothesis that institutional owners presumed to engage more on tax avoidance activities to take ascendance from cash flows saved from tax expenses, and this endorsed, by studies documented by (Chung et al., 2002; Sengupta, 2005; Shleifer and Vishny, 1986). that large shareholding have advantage to capture information and can bring benefits greater than minority investors from monitoring organization which lead to more engage in tax avoidance activities, for government ownership the results support our hypothesis that firms connected with governments or political connections positively engaged in tax avoidance activities which is consistent opinions of (Chan et al., 2013; Kim and Zhang, 2016b). Justifies this positive relationship mainly because of less incentive to disclose all information of companies including tax details.

Among control variables, the table 4 shows that companies with increase industry type tend to be encouraged to involve on tax avoidance . on the other hand LEVERG documented positive relationship between leverage and tax avoidance , consistent with (Badertscher et al., 2013; Richardson et al., 2013) 
Table 4 shows the results of multiple regression analysis using ROA dependent variable

\begin{tabular}{lccccc}
\hline Variables & $\begin{array}{c}\text { Predicted } \\
\text { sign }\end{array}$ & Coef & T-value & Sig & VIF \\
\hline Intercept & & -7.4 & -.73 & .465 & \\
Independent variables & - & $0.31166^{* *}$ & -1.93 & 0.055 & 1.84 \\
ETR1 & + & $.3618^{*}$ & -1.87 & 0.063 & 1.54 \\
ETR2 & - & $0.0129^{* *}$ & 0.42 & 0.0672 & 1.09 \\
LEVERG & - & .5435 & -0.27 & 0.787 & 1.06 \\
INDUS & 278 & & & & \\
Observations & .375 & & & & \\
Adjusted R-squared & 21.40 & & & & \\
F-test. & .000 & & & & \\
Prob $>$ F & & & & & \\
\hline
\end{tabular}

Note : table 4 report regression results using OLS , ETR is total expenses scaled by cash flows from operations, ROA is of income before tax scaled by total assets, LEVERG is the ratio of total long-term debts over total assets, INDTYP it dummy variable; representing three industry types "manufacturing, investment, and service sectors. $; * * * * *, *$ are significance levels at 1,5 and $10 \%$, respectively

\section{6- Conclusion}

This study investigates the effect of tax avoidance behavior on firm value. Based on a sample of 34 Palestinian listed firms over 2018-2011 period, we find out that Palestinian listed firms try to avoid taxes to get benefits from tax savings and increase cash flows, which lead to increase firm's value. On Palestinian context, our results are interesting, Palestine is unique environment, since investors rights are weakly shielded. Furthermore, Palestine stock exchange market not developed enough. This arguments leash firms to benefit from tax savings. Since tax rate in Palestine considered low comparing with other countries negative relationship with tax avoidance.

This study has spotlight on tax avoidance on unique environment in Palestine and thus extend literature that focused on developed countries. Simultaneously, considered as basis in Palestine and other Arab countries for future research in this area.

Although the last implications of this study, it still has limitations, one is limited sample scope. as Palestine exchange market has few listed firms, as small country with precarious political situations, however, the study boost the researchers to further research in tax avoidance in Palestine and middle eastern countries to better understand the relationship of ownership structure on tax avoidance practices and enhance corporate governance effectively . another future researches suggested is to focus more on effects of audit quality on tax avoidance , corporate governance mechanisms on tax avoidance, and how it could influenced by tax avoidance .

\section{References:}

Allingham, M.G., Sandmo, A., 1972. INCOME TAX EVASION: A THEORETICAL ANALYSIS 16.

Armstrong, C.S., Blouin, J.L., Jagolinzer, A.D., Larcker, D.F., 2015. Corporate governance, incentives, and tax avoidance. Journal of Accounting and Economics 60, 1-17. https://doi.org/10.1016/j.jacceco.2015.02.003

Ayers, B.C., Jiang, J. (Xuefeng), Laplante, S.K., 2009. Taxable Income as a Performance Measure: The Effects of Tax Planning and Earnings Quality. Contemporary Accounting Research 26, 15-54. https://doi.org/10.1506/car.26.1.1

Badertscher, B.A., Katz, S.P., Rego, S.O., 2013. The separation of ownership and control and corporate tax avoidance. Journal of Accounting and Economics 56, 228-250. https://doi.org/10.1016/j.jacceco.2013.08.005

Buijink, W., Janssen, B., Schols, Y., 2002. Evidence of the effect of domicile on corporate average effective tax rates in the European Union. Journal of International Accounting, Auditing and Taxation 11, 115-130. https://doi.org/10.1016/S1061-9518(02)00069-1

Bushman, R.M., Smith, A.J., 2003. Transparency, Financial Accounting Information, and Corporate Governance 23.

Cai, H., Liu, Q., 2009. Competition and Corporate Tax Avoidance: Evidence from Chinese Industrial Firms. The Economic Journal 119, 764-795. https://doi.org/10.1111/j.1468-0297.2009.02217.x

Chan, K.H., Mo, P.L.L., Zhou, A.Y., 2013. Government ownership, corporate governance and tax aggressiveness: evidence from China. Accounting \& Finance 53, 1029-1051. https://doi.org/10.1111/acfi.12043

Chen, S., Chen, X., Cheng, Q., Shevlin, T., 2010. Are family firms more tax aggressive than non-family firms? Journal of Financial Economics 95, 41-61. https://doi.org/10.1016/j.jfineco.2009.02.003 
Chen, Z., Cheok, C.K., Rasiah, R., 2016. Corporate Tax Avoidance and Performance: Evidence from China's Listed Companies 23.

Chung, R., Firth, M., Kim, J.-B., 2002. Institutional monitoring and opportunistic earnings management. Journal of Corporate Finance 20.

Derashid, C., Zhang, H., 2003. Effective tax rates and the "industrial policy" hypothesis: evidence from Malaysia. Journal of International Accounting, Auditing and Taxation 12, 45-62. https://doi.org/10.1016/S10619518(03)00003-X

Desai, M.A., Dharmapala, D., 2009. CORPORATE TAX AVOIDANCE AND FIRM VALUE. THE REVIEW OF ECONOMICS AND STATISTICS 12.

Desai, M.A., Dharmapala, D., 2008. Tax and Corporate Governance: An Economic Approach, in: Schön, W. (Ed.), Tax and Corporate Governance. Springer Berlin Heidelberg, Berlin, Heidelberg, pp. 13-30. https://doi.org/10.1007/978-3-540-77276-7 3

Desai, M.A., Dharmapala, D., 2006. Corporate tax avoidance and high-powered incentives. Journal of Financial Economics 79, 145-179. https://doi.org/10.1016/j.jfineco.2005.02.002

Dey, A., 2008. Corporate Governance and Agency Conflicts. Journal of Accounting Research. https://doi.org/10.1111/j.1475-679X.2008.00301.X

Dhaliwal, D., Heitzman, S., Zhen Li, O., 2006. Taxes, Leverage, and the Cost of Equity Capital. Journal of Accounting Research 44, 691-723. https://doi.org/10.1111/j.1475-679X.2006.00214.x

Dyreng, S.D., Hanlon, M., Maydew, E.L., Thornock, J.R., 2017. Changes in corporate effective tax rates over the past 25 years. Journal of Financial Economics 124, 441-463. https://doi.org/10.1016/j.jfineco.2017.04.001

Egger, P., Eggert, W., Winner, H., 2010. Saving taxes through foreign plant ownership. Journal of International Economics 81, 99-108. https://doi.org/10.1016/j.jinteco.2009.12.004

Fan, J.P.H., Wong, T.J., 2002. Corporate ownership structure and the informativeness of accounting earnings in East Asia\$. Journal of Accounting and Economics 25.

Frank, M.M., Lynch, L.J., Rego, S.O., 2009. Tax Reporting Aggressiveness and Its Relation to Aggressive Financial Reporting. The Accounting Review 84, 467-496. https://doi.org/10.2308/accr.2009.84.2.467

Gaaya, S., Lakhal, N., Lakhal, F., 2017. Does family ownership reduce corporate tax avoidance? The moderating effect of audit quality. Managerial Auditing Journal 32, 731-744. https://doi.org/10.1108/MAJ-02-20171530

Gebhart, M.S., 2017. Measuring Corporate Tax Avoidance - An Analysis of Different Measures. JUNIOR MANAGEMENT SCIENCE Bd. 2 Nr. 2 (2017)-. https://doi.org/10.5282/jums/v2i2pp43-60

Goh, B.W., Lee, J., Lim, C.Y., Shevlin, T., 2016. The Effect of Corporate Tax Avoidance on the Cost of Equity. The Accounting Review 91, 1647-1670. https://doi.org/10.2308/accr-51432

Hanlon, M., Heitzman, S., 2010a. A review of tax research. Journal of Accounting and Economics 50, $127-178$. https://doi.org/10.1016/j.jacceco.2010.09.002

Hanlon, M., Heitzman, S., 2010b. A review of tax research. Journal of Accounting and Economics 50, $127-178$. https://doi.org/10.1016/j.jacceco.2010.09.002

Huizinga, H., Nicodème, G., 2006. Foreign ownership and corporate income taxation: An empirical evaluation. European Economic Review 50, 1223-1244. https://doi.org/10.1016/j.euroecorev.2005.02.004

Kiesewetter, D., Manthey, J., 2017. The Relationship between Corporate Governance and Tax Avoidance Evidence from Germany Using a Regression Discontinuity Design. SSRN Electronic Journal. https://doi.org/10.2139/ssrn.2951699

Kim, C.F., Zhang, L., 2016a. Corporate Political Connections and Tax Aggressiveness. Contemporary Accounting Research 33, 78-114. https://doi.org/10.1111/1911-3846.12150

Kim, C.F., Zhang, L., 2016b. Corporate Political Connections and Tax Aggressiveness. Contemporary Accounting Research 33, 78-114. https://doi.org/10.1111/1911-3846.12150

Lin, S., Tong, N., Tucker, A.L., 2014. Corporate tax aggression and debt. Journal of Banking \& Finance 40, 227 241. https://doi.org/10.1016/j.jbankfin.2013.11.035

McGuire, S., Wang, D., Wilson, R., 2011. Dual Class Ownership and Tax Avoidance.

Minnick, K., Noga, T., 2010. Do corporate governance characteristics influence tax management? Journal of Corporate Finance 16, 703-718. https://doi.org/10.1016/j.jcorpfin.2010.08.005

Richardson, G., Taylor, G., Lanis, R., 2013. The impact of board of director oversight characteristics on corporate tax aggressiveness: An empirical analysis. Journal of Accounting and Public Policy 32, 68-88. https://doi.org/10.1016/j.jaccpubpol.2013.02.004

Salihu, I.A., 2016. Government Ownership and Corporate Tax Avoidance : Empirical Evidence from Malaysia.

Sengupta, P., 2005. The Association between Outside Directors, Institutional Investors and the Properties of Management Earnings Forecasts 43. https://doi.org/10.1111/j.1475-679X.2005.00174.x

Shleifer, A., Vishny, R.W., 1997. A Survey of Corporate Governance. The Journal of Finance 52, 737-783. https://doi.org/10.1111/j.1540-6261.1997.tb04820.x 
Shleifer, A., Vishny, R.W., 1986. large shareholders and corporate control.

Slemrod, J., 2007. Cheating Ourselves: The Economics of Tax Evasion. Journal of Economic Perspectives 21, 2548. https://doi.org/10.1257/jep.21.1.25

Wilson, R.J., 2009. An Examination of Corporate Tax Shelter Participants. The Accounting Review 84, 969-999. https://doi.org/10.2308/accr.2009.84.3.969

Wu, W., Rui, O.M., Wu, C., 2013. Institutional environment, ownership and firm taxation: Evidence from China ${ }^{1}$. Economics of Transition 21, 17-51. https://doi.org/10.1111/ecot.12001

Zimmerman, J.L., 1983. Taxes and firm size. Journal of Accounting and Economics 5, 119-149. https://doi.org/10.1016/0165-4101(83)90008-3 